\title{
Holly Herndon: a life across bits and atoms
}

\author{
Article \\ Published Version
}

Dzuverovic, L. (2016) Holly Herndon: a life across bits and atoms. Afterall Journal, 41. pp. 90-97. ISSN 1465-4253 doi: https://doi.org/10.1086/687091 Available at https://centaur.reading.ac.uk/57270/

It is advisable to refer to the publisher's version if you intend to cite from the work. See Guidance on citing.

To link to this article DOI: http://dx.doi.org/10.1086/687091

Publisher: The University of Chicago Press

All outputs in CentAUR are protected by Intellectual Property Rights law, including copyright law. Copyright and IPR is retained by the creators or other copyright holders. Terms and conditions for use of this material are defined in the End User Agreement.

\section{www.reading.ac.uk/centaur}

\section{CentAUR}

Central Archive at the University of Reading

Reading's research outputs online 

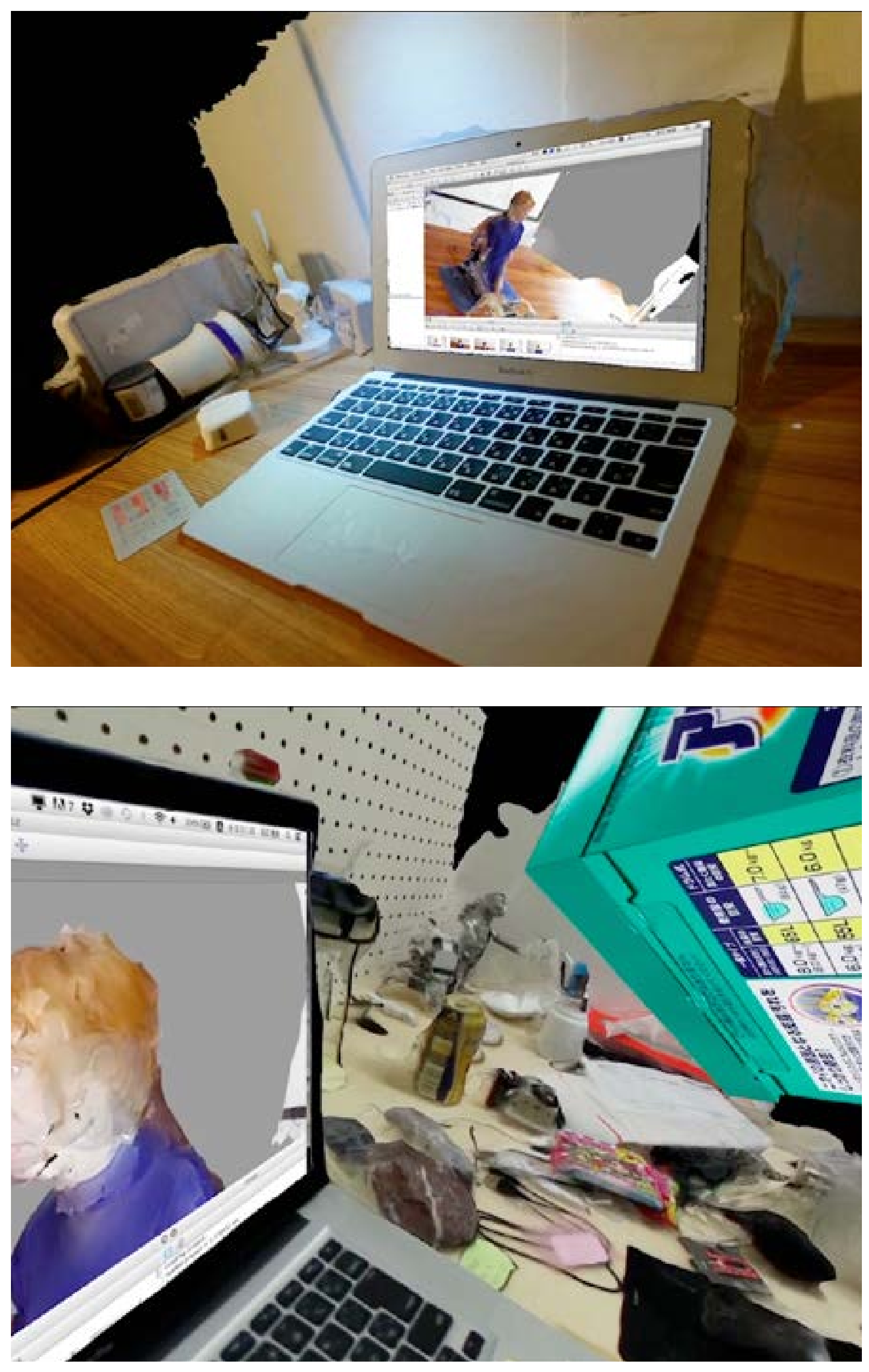


\title{
Holly Herndon: A Life Across Bits and Atoms
}

\author{
- Lina Džuverović
}

\begin{abstract}
Last summer I attended the now infamous workshop 'Wasting time on the Internet', led by Kenneth Goldsmith. ${ }^{1}$ Halfway into the day, just as we were all starting to become more comfortable, Goldsmith asked us to do something horrible, something that sent waves of panic across the room. His demand was initially met by a collective gasp. A few seconds later, composing ourselves, some of us reluctantly complied, while others became angry, attempting to refuse participation.

What Goldsmith had asked was that we each hand our personal laptop to whomever was sitting next to us. He then gave everyone permission to browse freely through all the files on the laptop just received. Without warning, without the chance to present an edited version of ourselves, he ripped our digital and analogue selves apart - our deepest secrets only a spotlight search away. The one person who declined was asked to explain: what was the worst that could happen? Discovery of a folder full of porn? Nude images meant to be seen by a lover? Obsessive prying into Facebook photos of a friend of a friend? Gossip? Financial details? Of course, we all knew that a single digital file was unlikely to cause anyone's
\end{abstract}

\section{Lina Džuverović locates Holly Herndon's 'voice-body' at the intersection of feminist vocalisations, accelerationist politics and the networks and surveillance of digital life.}

Holly Herndon's music is predicated on embracing and encouraging such exposure: much of her material is gathered by recording and repurposing daily activity on her laptop. Unlike much electronic music, where the laptop is primarily a means to synthesise sound, in Herndon's, her laptop is also the 'hardware'; its physical sounds in combination with the sounds made by Herndon as the user form the fabric of her compositions. Herndon's central preoccupation is precisely the exploration of the symbiotic and fluid relationship between the corporeal and the digital. She investigates ways in which electronic music performance can become an embodied experience, seeking to understand the place of her own body in the complex picture of the technological present. Informed by the writing of N. Katherine Hayles on the post-human, ${ }^{2}$ Herndon sees embodiment as more than corporality itself; it is a 'situated experience dependent on history and environment, unique to individuals within a collective'. ${ }^{3}$

Herndon has released three albums, an EP and several singles, which straddle a vast terrain of musical experimentation.

Recordings such as 'Locker Leak', on her latest album, Platform (2015), consist of poly-vocal tongue twisters that convey the feeling of being online, continuously bombarded by adverts; it offers a critique of the suffocating consumerism that is taking over the digital realm. Herndon's voice, in its many versions, spews out social media lingo and advertising catchphrases ("be the first of your friends to like Greek yogurt this summer') as it trips on itself, slows down and is repeatedly interrupted by snippets of anxiety-provoking sonic disturbance. Another track on the album, 'Chorus', is rich for external viewing.

1 Kenneth Goldsmith runs the module 'Wasting Time On The Internet' in the English Department at Penn State; see https://www.english.upenn.edu/courses/undergraduate/2015/spring/engl111.301 (last accessed on 21 December 2015). The session I attended took place in June 2015 at Galerija Nova, Zagreb as part of the ongoing 'Public Library' project initiated by Multimedijalni institut (MI2) and What How and for Whom (WHW). See https://www.memoryoftheworld.org (last accessed on 21 December 2015).

2 See N. Katherine Hayles, How We Became Posthuman: Virtual Bodies in Cybernetics, Literature, and Informatics, Chicago: The University of Chicago Press, 1999.

3 Holly Herndon, 'Embodiment in Electronic Music Performance', unpublished master's thesis, Oakland, CA: Mills College, 2010, p.4. 


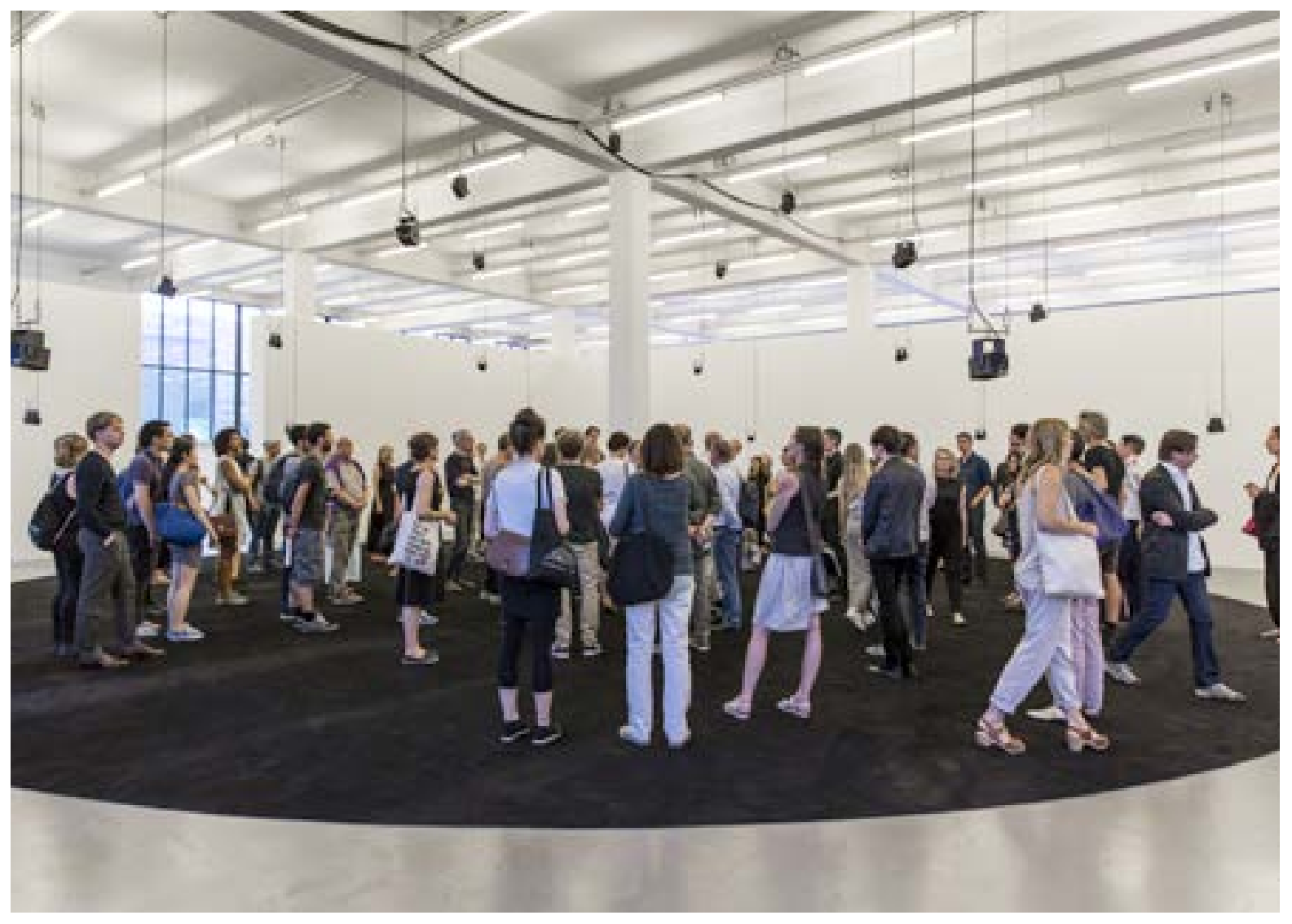

with exquisitely textured short samples reminiscent of 8-bit computer aesthetics, so well-crafted that they almost function as separate sonic objects. Such samples are woven together with multiple layers of Herndon's voice, oscillating between sounding human and machine-generated; the track gradually builds up before descending into a dynamic rhythm driven forward by a web of synthesised polyphonic voices.

At the other end of the album's spectrum lies a conceptual piece, 'Lonely At The Top', which consists of Herndon's speaking voice and an array of non-musical, concrete sounds referencing the phenomenon of Autonomous Sensory Meridian Response (ASMR), a physiological reaction to soft sounds and whispering. A growing online community has formed around ASMR, contributing countless videos that, when listened to through headphones, are supposed to trigger this pleasurable physical response. ${ }^{4}$ Herndon transposes the experience of ASMR videos typically accessed on YouTube into a recorded album track with an offline presence, thus performing a full loop. The 'tingling sensations' of ASMR are triggered by digital recordings of physical objects' sonic properties; Herndon brings such experiences back into the physical realm. ('everywhere and nowhere', a recent

\section{Herndon's central}

\section{preoccupation is the} exploration of the symbiotic and fluid relationship between the corporeal and the digital.

exhibition by Herndon and Mathew Dryhurst, and involving a host of other collaborators, presented a 23.2-channel sound installation and accompanying video works that introduced ASMR into the gallery space..$\left.^{5}\right)$

'Lonely At The Top' emerged out of Herndon's conversations with the Berlinbased artist Claire Tolan, who runs a regular radio show, You're Worth It, dedicated to ASMR and relaxation. Drawing on Herndon's immersion and interest in the

4 At the time of writing, a YouTube search for ASMR offered over two million results.

5 'everywhere and nowhere', Kunstverein in Hamburg, 6 August-13 September 2015. Apart from Mathew Dryhurst, other collaborators on this project were the Dutch design agency Metahaven, ASMR artist Claire Tolan and theorist Suhail Malik. 


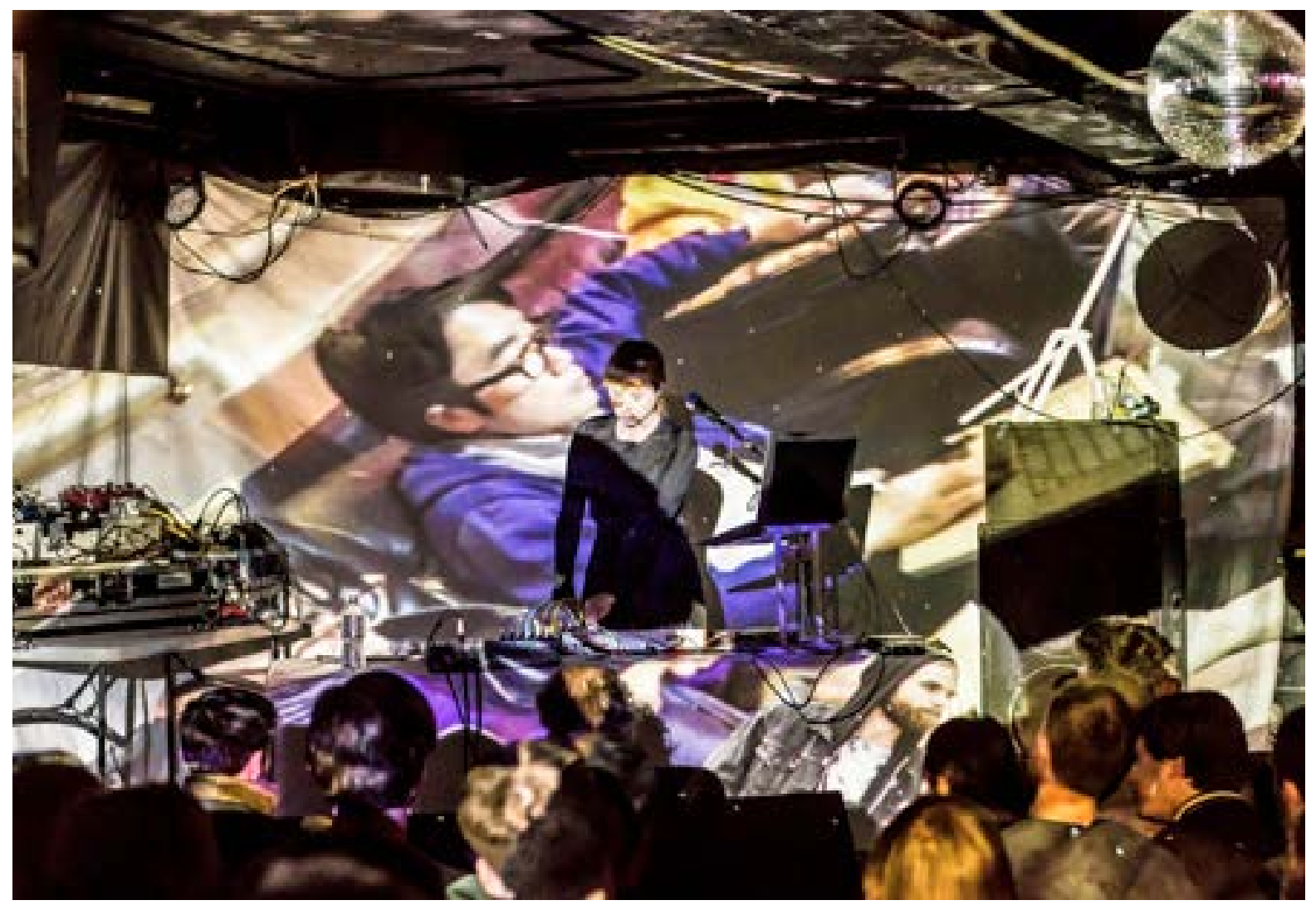

ASMR community, the track builds up a narrative that enacts an intimate experience between Herndon as the provider of a relaxation service and a client who has come in for a session. Based on an exchange between Herndon and Tolan about the coping strategies of the extremely wealthy (required to ease their anxiety about being at the top end of global inequality), the track combines Herndon's soothing voice with typical ASMR sounds (tapping, scratching, flowing water) to guide us through what the pair refer to as a 'kind of therapy for the 1\%' - a way to ease the guilt. ${ }^{6}$

In Herndon's music we are continuously reminded of the complex relations of voice, technology and body, and of the multitude of political entanglements across their triangulation. Steven Connor, writing on breath, ventriloquism and air, has proposed that "voice is not simply an emission of the body; it is also the imaginary production of a secondary body, a body double: a "voice-body"' ${ }^{7}$ It is this 'voicebody' that is at the centre of Herndon's project, constantly being twisted, exposed, modified, doubled, erased and brought back. Herndon's voices range from choral influences (Herndon's father was a preacher and she spent her childhood singing in choirs) to breathing (take 'Breathe', on the 2012 album Movement), whispers and words spoken aloud; all these occasionally disappear into moments of post-human, genderless sound. Although Herndon's vocal delivery is often pleasant, at times even seductive, she remains fully aware of the connotations of the female voice, and the fact that female vocal performance is still most often produced by male studio engineers. Her vocal distortions do not seek to 'clean up' the pitch or delivery, but quite the opposite: she can make the voice ugly, abrasive, un-gendered. Equally, the reassurance of the maternal voice and the ways in which urban space is regulated by soft-spoken yet authoritative female voices (public transport announcements, automated supermarket checkouts), as pointed to by Nina Power, are

6 Claire Tolan, quoted in Ruth Saxelby, '10 Radical Ideas that Inspired Holly Herndon's Platform', Fader, 21 May 2015, available at http://www.thefader.com/2015/05/21/radical-ideas-that-inspired-hollyherndon-platform (last accessed on 21 December 2015)

7 Steven Connor, 'The Strain of the Voice' (2004), available at http://stevenconnor.com/strains.html (last accessed on 21 December 2015). This essay first appeared in a German translation by Holger Wölfle, in Brigitte Felderer (ed.), Phonorama: Eine Kulturgeschichte der Stimme als Medium, Berlin: Matthes and Seitz, 2004, pp.158-72. 
echoed in Herndon's play with her morphing voice's multitude of roles and tones. ${ }^{8}$

In performance history, voice as destabilising force stretches back across the twentieth-century. Antonin Artaud famously became the plague - contorting, snorting, gasping, screaming on the floor - at his 1933 Sorbonne lecture 'Le Théâtre et la peste' ('The Theatre and the Plague'), in an instance of a 'voice-body' that engendered illness. ${ }^{8}$ This

\section{Herndon's work points to the delicate dance between surveillance and its counter-narratives, and the hitherto impossible witnessing now enabled by technology.}

early instance of the voice-body on edge was a turning point, and has since been evoked by improvisers across performance art and experimental sonic practice, one notable example being Diamanda Galás's 1990 Plague Mass performances, in which her four-octave voice, enhanced by electronics, strained to become the pain suffered by AIDS victims. ${ }^{9}$ Much like Herndon's repurposing of a cacophony of digital and analogue activities, Cathy Berberian's Stripsody of 1966 incorporated the sounds not just of internal turmoil but of the fast changing media-driven world, as vocalised in comicstrip-style sound effects. Joan La Barbara's work has, since the 1960 s, expanded the possibilities of vocal composition and performance through the introduction of multiphonic sounds - sighing, breathing, inhaling or whispering, for example. These performances often sound machine-like, repulsive or frightening, and are a far cry from classical aural traditions aimed at inspiring pleasure or awe in the listener.

In the mid-1970s, Yugoslavian-born sound poet Katalin Ladik began performing visual scores made from the dressmaking patterns she used to make clothes for her family, in a form of an unprecedented feminist agency - literally vocalising the grief of daily drudgery in the gallery space - and Herndon's 'performing' of the laptop, albeit in a very different way, may be said to evoke the neo-machine-work of contemporary intellectual labour. Female musicians associated with the Feminist Improvising Group (FIG), established by Maggie Nicols and Lindsay Cooper in London in 1977, took an approach of 'queering' the improvisational space and 'demanding queer listening'; ${ }^{10}$ by brazenly bringing personal, political and sexual identity into the arena of improvised music, FIG established a firm space for women practitioners in this male-dominated milieu. Herndon's vocal transformations also recall Laurie Anderson's practice of 'audio drag', or filtering her own voice electronically to inhabit and create a male persona; initially referred to as 'the voice of authority', he later came to be named Fenway Bergamot.

Herndon can also be connected to feminist musicians associated with Mills College in Oakland, California, where she did her master's. ${ }^{11}$ Most notably, her explorations expand the legacy of the composer Pauline Oliveros, who became the director of the San Francisco Tape Music Center when it moved to Mills in 1967 (later becoming the Center for Contemporary Music) - in particular Oliveros's early experiments with tape music in pieces such as Bye Bye Butterfly (1965), which morphs and manipulates a loop taken from Giacomo Puccini's opera Madama Butterfly (1904) through a delay setup. In this pioneering feminist work, the operatic voice emerges as horrifically wounded, sinister and damaged, presenting, as Oliveros puts it, a 'farewell not only to the music of the nineteenth century but also to the system of polite morality of that age and its attendant institutionalised oppression of the female sex'. ${ }^{12}$ as an audio recording at https://soundcloud.com/uclurbanlab/nina-power-soft-coercion (last accessed on 21 December 2015).

9 Artaud's lecture is described in detail in The Diary of Anaïs Nin, Vol. I (1931-1934), New York: Swallow Press, 1966, pp.191-93.

10 The performances, which took place on 12 and 13 October 1990 at the Cathedral of Saint John the Divin in New York, are documented on Diamanda Galás, Plague Mass (1984-End of the Epidemic) (Mute Records, 1991).

11 Julie Dawn Smith, 'Playing Like a Girl: The Queer Laughter of the Feminist Improvising Group,' in Daniel Fischlin and Ajay Heble (ed.), The Other Side of Nowhere: Jazz, Improvisation, and Communities in Dialogue, Middletown, CT: Wesleyan University Press, 2004, pp.224-43.

12 Herndon is currently working on a PhD at Stanford University.

13 Pauline Oliveros, Deep Listening: A Composer's Sound Practice, Kingston, NY: Deep Listening Publications, 2005, p.92. 


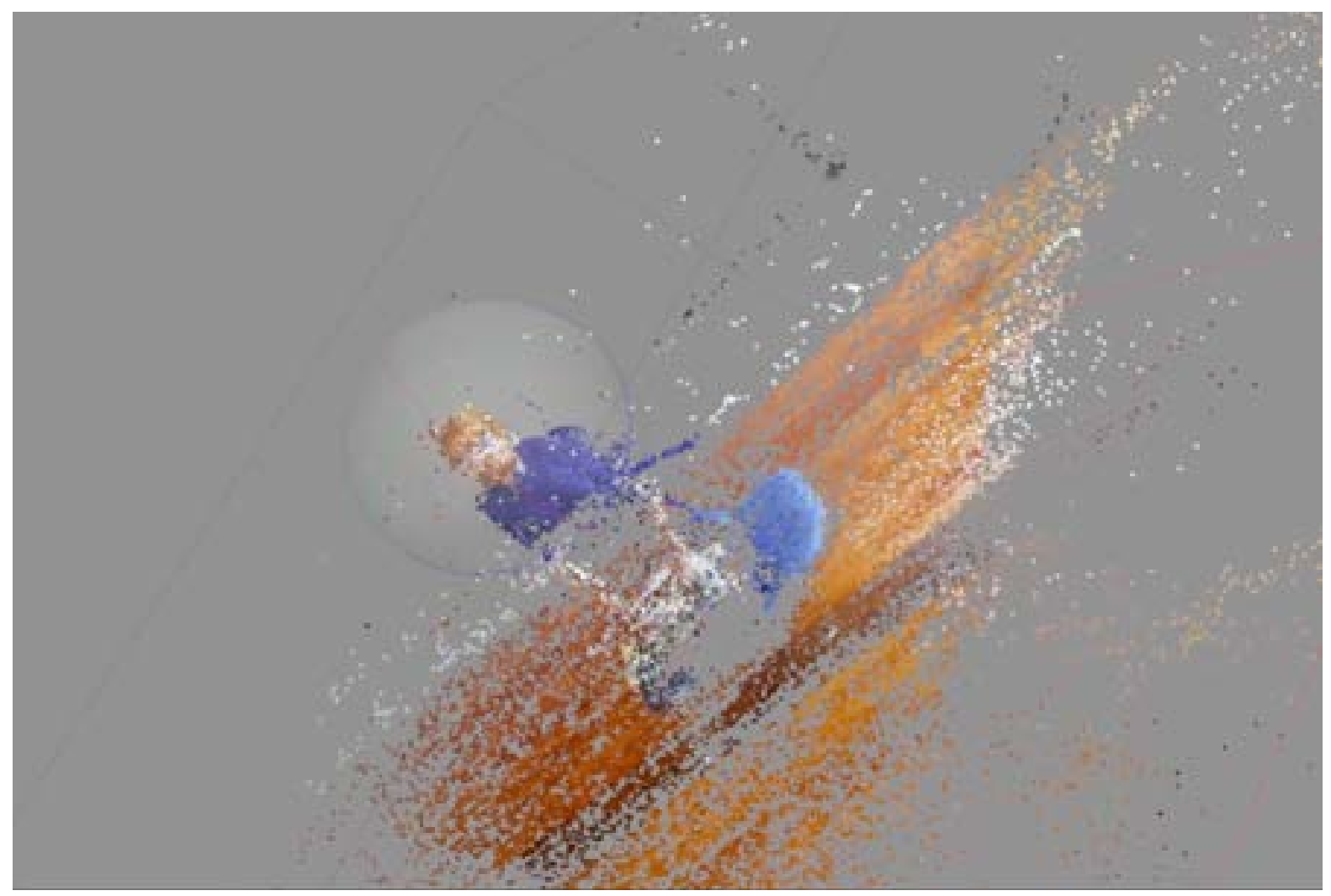

But to only contextualise Herndon's work in the lineage of twentieth-century female vocal exploration risks veering into an essentialist quest for a vocal equivalent of écriture féminine (following Hélène Cixous) - a unique inscription of gender into sound. Whilst the heritage of experimentation with the female voice is a powerful and important emancipatory site, this is just one facet of Herndon's work. Her vocal explorations and feminism operate as part of a more complex techno-reality in which the voice appears amidst a spectrum of other components of the 'entire field of sound', as John Cage described it. ${ }^{13}$ Her own musical influences are eclectic and at times unexpected - her work is as indebted to the history of techno and sampling as it is to more leftfield forms. When invited to create a mix for FACT magazine, for instance, Herndon responded with an eclectic selection that bridged Japanese installation artist Yutaka Makino's soundscapes, the group Ugandan Speed Trials's dubstep and Norwegian improviser Maja Ratkje's exquisite vocals. ${ }^{14}$

Herndon's far-ranging collaborative efforts have also led her into exhibition- based projects and the sphere of contemporary art. As well as the aforementioned 'everywhere and nowhere', a notable example is her 2013 collaboration with artist Conrad Shawcross, for which Herndon composed a track for his robot Ada (named after Ada Lovelace, the famed British mathematician and the first computer programmer). ${ }^{15}$ The work combined multichannel spatialisation and algorithmic vocal processing to produce a sonic environment that was responsive to the robot's movements, giving the impression of progression: Ada became more 'confident' over the performance.

It is this slippage, across collaborators, disciplines and media, that gives some credence to how Herndon chooses to describe her recorded works, not as albums but as platforms for discourse and collaboration. The very act of naming her latest album Platform connects Herndon to recent 'accelerationist' theory, and in particular, to its proposition that information technologies, whilst certainly tools in capitalist production, have the potential to act as springboards for non-

14 John Cage, 'The Future of Music: Credo' (1937), Silence: Lectures and Writings, Middletown, CT: Wesleyan University Press, 1973, p.4.

15 'FACT mix 368: Holly Herndon', FACT Magazine, 4 Febrvary 2013, available at http://www.factmag.com/ 2013/02/04/fact-mix-368-holly-herndon/ (last accessed on 21 December 2015).

16 The Ada Project (begun 2013) is an installation by Shawcross that involves a series of musical commissions by contemporary composers. It has been presented at The Vinyl Factory Space at The Brewer Street Car Park, London, Palais de Tokyo, Paris and elsewhere. See http://conradshawcross.com/ project/the-ada-project-2013 (last accessed on 21 December 2015). 


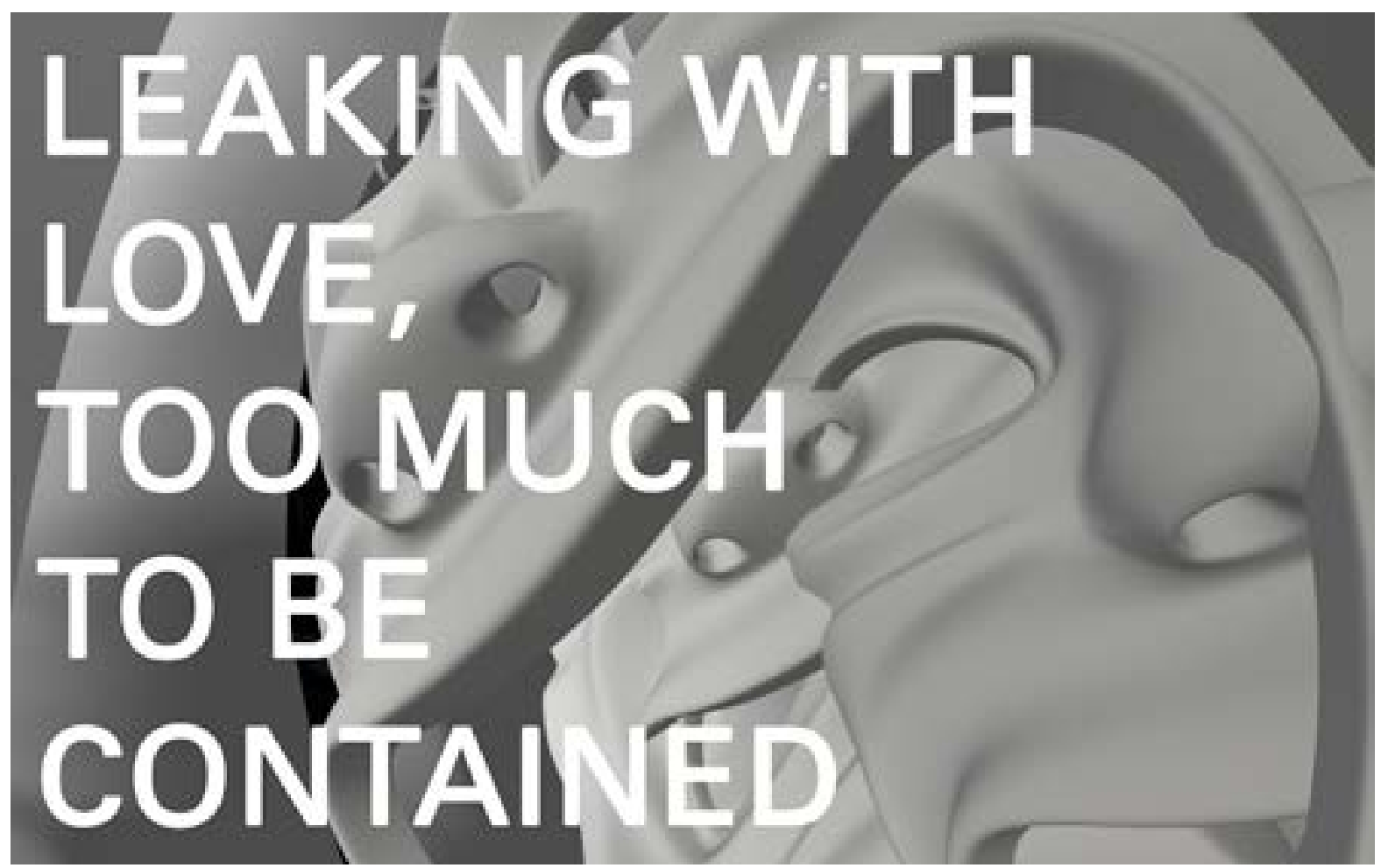

capitalist modes of production if utilised in an informed and sophisticated way. To quote Alex Williams and Nick Srnicek's ‘\#ACCELERATE MANIFESTO' of 2013: 'These material platforms of production, finance, logistics and consumption can and will be reprogrammed and reformatted towards post-capitalist ends. ${ }^{, 16}$

Accelerationist notions of the use of information technologies (algorithms, network analysis, agent-based modelling, big data analytics, non-equilibrium economic models) for forming collective and structural alternatives are further carried into Herndon's compositional techniques and subject matter. In the Platform track 'Home', Herndon foregrounds the exposure and alienation inherent in data collection and surveillance ('I can feel you in my room / Why was I assigned to you? / I know that you know me better than I know me') before suggesting a loss of identity caused by this erosion of privacy ('I don't know which me to be / On my own'). But in another track on the album, 'Unequal' - which is sonically akin to a chorus of cyborgs planning a revolution - Herndon hints at both intimacy and collectivity ('Honesty / Fight for each other / For one, as one / Why? Why are we unequal? / "To change the shape of our future, to be unafraid, to break away"'). Structurally, these ideas are also applied through Herndon's focus on exposing the production mechanisms behind her compositions. For example, Herndon's and Dryhurst's 2012 live collaboration with the Iranian philosopher Reza Negarestani was arranged to incorporate stage photographers (as triggers for particular sounds), laptops embedded in the audience, the audience's mobile phones and 'dormant instruments' scattered across the space, as well as applause, into the performance. ${ }^{17}$ This eschewing of the authorial and attempts towards a distributed compositional platform are echoed in Negarestani's own writing on the 'labour of the inhuman', which problematises the possibility of attaining forms of universality and collectivism. $^{18}$

These platforms are also underpinned by an approach that Herndon terms

17 Alex Williams and Nick Srnicek, “\#ACCELERATE MANIFESTO for an Accelerationist Politics', 14 May 2013, available at http://criticallegalthinking.com/2013/05/14/accelerate-manifesto-for-an-accelerationistpolitics/ (last accessed on 21 December 2015). For a detailed analysis of this view, see Tiziana Terranova, 'Red Stack Attack! Algorithms, Capital and the Automation of the Common', in Robin Mackay and Armen Avanessian (ed.), \#Accelerate: The Accelerationist Reader, Falmouth: Urbanomic, 2014, pp.379-401.

18 Herndon, Negarestani and Dryhurst's live work was created for the festival 'Activating the Medium', organised by 23 five, The Lab, San Francisco, 28 April 2012. A recording can be accessed at https://soundcloud. $\mathrm{com} /$ hollyherndon/holly-herndon-mat-dryhurst (last accessed on 21 December 2015).

19 See Reza Negarestani, 'The Labor of the Inhuman', in R. Mackay and A. Avanessian (ed.), \#Accelerate: The Accelerationist Reader, op. cit., pp.425-67. 
sousveillance. As opposed to surveillance - the invasive procedure through which individual behaviour is monitored by organised, governmental or corporate entities for the purpose of collecting and using data, the term sousveillance refers to observation from below. ${ }^{19}$ In sousveillance it is the individual who is doing the observation, and often the recording - a grassroots response to the knowledge that we are being continuously watched and data-mined, with cameras and listening devices increasingly used as evidence against police brutality and other abuses of power (last summer saw the introduction of numerous mobile apps allowing instant uploads should a phone be confiscated or destroyed). Herndon's turn to sousveillance is an acute reminder of the present political moment; it not only points to the delicate dance between surveillance and its counternarratives, but also to the hitherto impossible witnessing now enabled by technology. ${ }^{20}$ But if the democratisation of media enables instant recording and observation of our own behaviour, it also potentially spells our demise; Herndon's sousveillance brings to mind the chilling opening sentence of Rabih Mroue's theatrical performance-lecture The Pixelated Revolution (2012) - 'Syrian protestors are filming their own death'21 - in reference to the simultaneity, and consequent flattening, of lived experience and its documentation in the digital era.

In a recent email interview with Chelsea Manning, the former US Army intelligence analyst serving a prison sentence for supplying information to WikiLeaks, Herndon described herself and Dryhurst as 'musicians who are interested in creating new fantasies for new realities'. ${ }^{22}$ Aligning themselves with Manning's cause (and fundraising towards her legal fund), Herndon and Dryhurst and their collaborators Metahaven, amongst others, suggest an alternative that Metahaven has described as a 'radical aesthetic with progressive politics', inspired by philosopher and activist Cornel West's claim that 'justice is what love looks like in public'. ${ }^{23}$ Yet it would be naïve not to question the extent to which electronic music and design, however progressive, can actually be effective in the accelerationists' larger aim of unleashing the full power of technology for post-capitalist purposes. ${ }^{24} \mathrm{In}$ the interview, Manning appropriately questions the use of the term 'radical' - 'Is it radical to seek justice? Is it radical to be rescued by love?' - an understandable view from someone three years into a jail sentence for an undeniably radical act.

Even so, Herndon's work, and her methods, takes us far beyond the traditional concerns of a contemporary electronic musician. Her experimentation rarely seems gratuitous; rather, it tends to be purposefully directed toward a particular goal, usually seeking to create a space for a specific exchange or collaboration. And if Herndon's work is understood in terms of the platforms it creates, and not simply as sonic output, then certain accelerationist potentialities begin to emerge. Perhaps then, returning to Goldsmith's forcible separation of digital and physical selves, an immersion into somebody else's digital universe however momentary - has the potential to to open up possibilities, demonstrating that, after all, the network can only reach its potential once we allow it to do so. Herndon's oeuvre may be understood as just such a network; one that, through its very existence, facilitates change.

The French prefix sur indicates 'above', so that surveillance means 'watching from above'; sous indicates 'below', and sousveillance 'watching from below'.

21 Her live shows have on occasion been accompanied by projected images of the event's Facebook page and the social media profiles of audience members.

22 Mrovés The Pixellated Revolution was a performance-lecture commissioned by dOCUMENTA(13) in 2012. A fifteen-minute extract can be found at https://vimeo.com/63916014 (last accessed on 25 December 2015).

23 “We are at the very beginning of a new epoch:” Chelsea Manning on the luxury of privacy' (interview by H. Herndon, M. Dryhurst, Metahaven and Jacob Appelbaum), PAPER, 1 September 2015, available at http://www.papermag.com/we-are-at-the-very-beginning-of-a-new-epoch-chelsea-manning-on-thelux-1427637348.html (last accessed on 21 December 2015).

24 Cited in ibid.

25 A. Williams and N. Srnicek, ‘\#ACCELERATE MANIFESTO’, op. cit. 